\title{
Genetic engineering of an industrial strain of Saccharopolyspora erythraea for stable expression of the Vitreoscilla haemoglobin gene (vhb)
}

\author{
Peter Brünker, Wolfgang Minas, Pauli T. Kallio and James E. Bailey \\ Author for correspondence: James E. Bailey. Tel: +41 1633 3403. Fax: +4116331051. \\ e-mail : bailey@biotech.biol.ethz.ch
}

Institute of Biotechnology, ETH Z.ürich, 8093 Zürich, Switzerland

\begin{abstract}
Several Actinomycetes/Streptomycetes expression vectors are described for expression of the Vitreoscilla haemoglobin gene (vhb) in an industrial erythromycin-producing strain of Saccharopolyspora erythraea. Cloning of vhb under the control of either the thiostrepton-inducible PtipA promoter or the constitutive PermE* promoter led to the production of chemically active haemoglobin (VHb) in Streptomyces lividans TK24 transformed with these constructs. However, the plasmids could not be transformed into Sac. erythraea. Transformants of Sac. erythraea and/or exconjugants were obtained using a novel Escherichia colilstreptomyces shuttle vector comprised of vhb under the control of the PermE* promoter, the Streptomyces plasmid pIJ350 origin of replication, the thiostrepton-resistance gene (tsr) for selection, and the orit region which is necessary for conjugal transfer. Increased plasmid stability in Sac. erythraea was obtained by construction of a vector for chromosomal integration. This vector contained the Streptomyces phage $\phi \mathrm{C} 31$ attachment site for chromosomal integration and vhb expressed under the PmerR promoter and was stably maintained in the chromosome of Sac. erythraea. Shake-flask cultivations of the transformed Sac. erythraea strain with the chromosomally integrated vhb gene show that vhb is expressed in an active form. The corresponding amount of erythromycin produced in the vhbexpressing strain was approximately $60 \%$ higher relative to the original VHbnegative strain.
\end{abstract}

Keywords : erythromycin, integration vector, phage $\phi \mathrm{C} 31$

\section{INTRODUCTION}

Erythromycin is a clinically important and potent macrolide antibiotic produced by the Gram-positive actinomycete Saccharopolyspora erythraea (Weber et al., 1985). It is used to treat infections by several prokaryotic pathogens such as Streptococcus, Staphylococcus, Mycoplasma, Ureaplasma, Chlamydia and Legionella (Nakayama, 1984). The current annual production of erythromycin is more than 2 tonnes and the pharmaceutical demand for this antibiotic is increasing annually.

Despite intensive efforts using classical strain development techniques and bioprocess optimization

Abbreviation: VHb, Vitreoscilla haemoglobin. methods, maximum attainable final concentrations of erythromycin using Sac. erythraea are low in comparison to other industrially produced antibiotics such as penicillin or cephalosporin C. Since traditional methods have not greatly increased erythromycin production, our approach was to modify Sac. erythraea by metabolic engineering (Bailey, 1991) to improve its overall productivity. Special emphasis was placed on improving oxygen metabolism, as this might be a limiting factor for erythromycin synthesis in this organism.

Previous experiments using other industrially important organisms have shown that expression of a bacterial haemoglobin gene $(v b b)$ originally isolated from Vitreoscilla sp. (Khosla \& Bailey, 1988a) can significantly improve cell growth and productivity (Khosla $\&$ 
Bailey, 1988b). It was demonstrated that expression of vbb in Acremonium chrysogenum led to a threefold increase in cephalosporin C production (DeModena et al., 1993). Furthermore, the yield of human tissue plasminogen activator (tPA) from Chinese hamster ovary cells (Pendse \& Bailey, 1994), L-lysine production of Corynebacterium glutamicum (Sander et al., 1994), and total protein secretion, neutral protease activity and $\alpha$-amylase activity of Bacillus subtilis (Kallio \& Bailey, 1996) were all increased in the presence of active Vitreoscilla haemoglobin ( $\mathrm{VHb}$ ) in these organisms. Even in transgenic tobacco plants expressing $v h b$, a positive effect on an oxygen-dependent step in nicotine synthesis was observed which led to a $34 \%$ increase in nicotine content (Holmberg et al., 1997). The recombinant tobacco plants also showed earlier germination and flowering and were able to produce plant material (dry weight) faster relative to the controls.

These examples of the beneficial effects of $\mathrm{VHb}$ in a variety of classes of organisms prompted us to clone and express the haemoglobin gene from Vitreoscilla sp. into Sac. erythraea.

In this work we describe for the first time the stable chromosomal integration of a $v h b$ expression cassette into an industrial erythromycin-producing strain of Sac. erythraea and show that erythromycin production in the recombinant $v b b$-expressing strain was significantly enhanced compared to the original strain.

\section{METHODS}

Bacterial strains, plasmids and culture conditions. All bacterial strains and plasmids used are listed in Table 1. Escherichia coli strains were grown at $37^{\circ} \mathrm{C}$ in either $2 \times \mathrm{YT}$ or LB liquid medium (Sambrook et al., 1989) or on $2 \times$ YT plates containing $1.6 \%(\mathrm{w} / \mathrm{v})$ agar. Streptomyces lividans strains were maintained on R5 plates (Hopwood et al., 1985) or incubated in SM liquid medium (Birr et al., 1989) at $30^{\circ} \mathrm{C}$. Sac. erythraea was grown in the same media at $34{ }^{\circ} \mathrm{C}$. $S$. lividans stocks were stored as spore solutions in $20 \%(\mathrm{v} / \mathrm{v})$ glycerol at $-20^{\circ} \mathrm{C}$, whereas mycelial stocks of Sac. erythraea were kept at $-80^{\circ} \mathrm{C}$ in $30 \%(\mathrm{v} / \mathrm{v})$ glycerol. Media were supplemented with the appropriate antibiotics (100 $\mu \mathrm{g}$ ampicillin $\mathrm{ml}^{-1}, 12 \cdot 5 \mu \mathrm{g}$ thiostrepton $\mathrm{ml}^{-1}, 50 \mu \mathrm{g}$ kanamycin $\mathrm{ml}^{-1}$, $30 \mu \mathrm{g}$ chloramphenicol $\mathrm{ml}^{-1}$, or $40 \mu \mathrm{g}$ nalidixic acid $\mathrm{ml}^{-1}$ ) as needed.

Isolation and manipulation of DNA. Minipreparations of plasmid DNA were done by an alkaline lysis method as described by Lee \& Rasheed (1990). Genomic DNA from $S$. lividans and Sac. erythraea was isolated according to protocols by Hopwood et al. (1985). Restriction enzymes, T4 DNA ligase, alkaline phosphatase, Klenow polymerase and Pwo polymerase were obtained from commercial sources and used as recommended by the manufacturers. Standard DNA techniques and Southern blot analyses were performed as described by Sambrook et al. (1989). PCR for amplification of PmerR and $v h b$ was performed with a GeneAmp 9600 PCR system (Perkin Elmer) using template-specific conditions. All PCR fragments used for subsequent expression of $v b b$ were confirmed by DNA sequencing using the dideoxynucleotide chain-termination method (Sanger et al., 1977).
Transformation of bacterial cells. Competent E. coli XL-1 Blue (Bullock et al., 1987) and ET12567 (MacNeil et al., 1992) were prepared and transformed by the method of McKenney et al. (1981). Preparation of S. lividans protoplasts and PEGmediated transformation were performed according to the protocol of Hopwood et al. (1985). For Sac. erythraea, this protocol was slightly modified. The cells were grown for $4-5 \mathrm{~d}$ in TSB (Oxoid) containing $0.25 \%(\mathrm{w} / \mathrm{v})$ glycine. For protoplast formation, the final concentration of lysozyme was $8 \mathrm{mg} \mathrm{ml}^{-1}$ (instead of $4 \mathrm{mg} \mathrm{ml}^{-1}$ for S. lividans) and PEG-3350 (Sigma) was used instead of PEG-1000 in the transformation reaction. Furthermore, for transformation of Sac. erythraea, non-methylated DNA isolated from E. coli ET12567 was used. Since regeneration of Sac. erythraea protoplasts seemed to be much slower than that of $S$. lividans protoplasts, the antibiotic overlay was performed $48 \mathrm{~h}$ after transformation. Conjugational transfer of plasmids from E. coli to Sac. erythraea was performed on plates as described by Bierman et al. (1992).

Detection of $\mathbf{V H b}$ and activity assays. $v b b$-expressing strains of S. lividans and Sac. erythraea were grown in $200 \mathrm{ml} \mathrm{SM}$ medium for $4-5 \mathrm{~d}$ at $30^{\circ} \mathrm{C}$ and $34^{\circ} \mathrm{C}$, respectively, in a rotary shaker incubator at 250-300 r.p.m. Cells were harvested, washed twice in buffer $(100 \mathrm{mM}$ Tris $/ \mathrm{HCl} \mathrm{pH} \mathrm{7.5,50 \textrm {mM }}$ $\mathrm{NaCl}, 1 \mathrm{mM}$ EDTA), resuspended in $20 \mathrm{ml}$ buffer and disrupted by passing three times through a French press (Aminco SLM Instruments) operated at 1000-1500 p.s.i. (6.9-10.3 MPa). The soluble cellular fraction was used for Western blots (Winston et al., 1987) after separating the proteins by $15 \%$ SDS-PAGE and for determination of the COdifference spectrum (Webster \& Liu, 1974). The rabbit anti$\mathrm{VHb}$ serum was obtained from Cocalico Biologicals. The protein concentration in the samples was determined by the method of Bradford (1976) using Bio-Rad dye reagent and bovine serum albumin as the standard. Total protein concentration of samples from shake-flask cultivations was determined as described by Gerhardt et al. (1994).

Shake-flask cultivations of Sac. erythraea. A seed culture of $30 \mathrm{ml}$ vegetative medium I [per litre: $16 \mathrm{~g}$ Argo corn starch, $10 \mathrm{~g}$ dextrin, $15 \mathrm{~g}$ soybean flour, $2.5 \mathrm{~g} \mathrm{NaCl}, 5 \mathrm{ml}$ corn-steep liquor, $1 \mathrm{~g}\left(\mathrm{NH}_{4}\right)_{2} \mathrm{SO}_{4}, 6 \mathrm{ml}$ soybean oil and $4 \mathrm{~g} \mathrm{CaCO}_{3}, \mathrm{pH}$ adjusted to 6.5 ] in $250 \mathrm{ml}$ baffled shake flasks was inoculated with $1.5 \mathrm{ml}$ glycerol stock and incubated for $40 \mathrm{~h}$ at $34^{\circ} \mathrm{C}$ with 250 r.p.m. agitation [ 2 inch $(5 \mathrm{~cm})$ stroke] in a humidized rotary shaker incubator (Infors). Seed culture $(3 \mathrm{ml}$ ) was inoculated into $27 \mathrm{ml}$ half-strength fermentation medium I (F1) [per litre: $35 \mathrm{~g}$ corn starch, $32 \mathrm{~g}$ dextrin, $33 \mathrm{~g}$ soybean flour, $7 \mathrm{~g} \mathrm{NaCl}, 20 \mathrm{ml}$ corn-steep liquor, $2 \mathrm{~g}\left(\mathrm{NH}_{4}\right)_{2} \mathrm{SO}_{4}, 6 \mathrm{ml}$ soybean oil and $8 \mathrm{~g} \mathrm{CaCO}_{3}, \mathrm{pH}$ adjusted to 6.5]. Cultivations for erythromycin production were run for $9 \mathrm{~d}$ with the following daily addition of soybean oil $(0 \cdot 2 \mathrm{ml}$, days $0-6)$ and $n$-propanol $(0 \cdot 1 \mathrm{ml}$, days $0-5$ and $0 \cdot 15 \mathrm{ml}$, days $6-9)$ starting at the day of inoculation of F1. The shake flasks were weighed daily and sterile water was added to compensate for evaporation if necessary.

Erythromycin bioassay. The titres of erythromycin produced by the industrial Sac. erythraea strain and its genetically engineered derivative were determined using a conventional bioassay with commercially available erythromycin (Fluka) as a standard. Portions $(35 \mathrm{ml})$ of test medium $\left[27.5 \mathrm{~g} \mathrm{TSB} \mathrm{l}^{-1}, 2\right.$ $\mathrm{g}$ glucose $\mathrm{l}^{-1}, 2 \%(\mathrm{w} / \mathrm{v})$ agar] were poured into Petri dishes $(12 \times 12 \mathrm{~cm})$. Once the medium was solidified, a second layer consisting of $35 \mathrm{ml}$ test medium containing $35 \mu \mathrm{l}$ of a Micrococcus luteus overnight culture (grown $18 \mathrm{~h}$ at $30^{\circ} \mathrm{C}$ in LB), was added. The erythromycin titre was determined by pipetting $10 \mu \mathrm{l}$ culture supernatant (or appropriate dilutions in 
Table 1. Bacterial strains and plasmids

\begin{tabular}{|c|c|c|}
\hline Strain/plasmid & Description & Reference/source \\
\hline \multicolumn{3}{|l|}{ Strains } \\
\hline E. coli XL-1 Blue & $\begin{array}{l}\text { recA1 endA1 gyrA96 thi-1 hsdR17 supE44 relA1 lac }\left[\mathrm{F}^{\prime} \text { proAB }\right. \\
\left.\text { lacl } \mathrm{Z} \Delta \mathrm{M} 15 \operatorname{Tn} 10\left(\mathrm{Tet}^{\mathrm{R}}\right)\right]\end{array}$ & Bullock et al. (1987) \\
\hline E. coli $\mathrm{ET} 12567$ & $\begin{array}{l}\text { supE44 hsdS20 }\left(\mathrm{r}_{\mathrm{B}}^{-} \mathrm{m}^{-}{ }_{\mathrm{B}}\right) \text { ara-14 proA2 lacY galK2 rpsL20 xyl-5 mtl-1 } \\
\text { dam }^{-} \mathrm{dcm} \mathrm{cm}^{-} \text {hsdM }{ }^{-} \mathrm{Cm}^{\mathrm{R}}\end{array}$ & MacNeil et al. (1992) \\
\hline E. coli $\mathrm{S} 17.1$ & recA thi pro hsdR- $\mathrm{M}^{+} \mathrm{RP} 4: 2-\mathrm{Tc}: \mathrm{Mu}: \mathrm{KmTn} 7 \mathrm{~T}^{\mathrm{R}} \mathrm{Sm}^{\mathrm{R}}$ & Simon et al. (1983) \\
\hline S. lividans TK24 & $\mathrm{SLP}^{-} \mathrm{SLP}^{-}$str-6 & Hopwood et al. (1983) \\
\hline S. lividans TK64 & SLP2- SLP3- pro-2 str-6 & Hopwood et al. (1985) \\
\hline Sac. erythraea & Industrial erythromycin-producing strain & Solidago AG \\
\hline M. luteus ATCC 9341 & Test organism for erythromycin bioassay & ATCC \\
\hline \multicolumn{3}{|l|}{ Plasmids } \\
\hline plC19H & $\operatorname{lac} Z \alpha$ & Marsh et al. (1984) \\
\hline pIJ6021 & PtipA & Takano et al. (1995) \\
\hline pIJ4090 & PermE* & Bibb \& Janssen (1986) \\
\hline pETR355 & $v h b$ under the control of PermE $E^{*}$ & This work \\
\hline pETR364 & $v h b$ under the control of PtipA & This work \\
\hline pETR388 & PmerR in $\mathrm{pIC19H}$ & This work \\
\hline pETR407 & $v h b$ under the control of PmerR in pETR388 & This work \\
\hline pETR419 & PermE $E^{*}-v b b$ and oriT in pJOE875 & This work \\
\hline pETR428 & $\phi \mathrm{C} 31$ att site (from pJOE706) in pETR407 & This work \\
\hline pETR432 & pETR428 containing $t s r$ & This work \\
\hline pETR451 & As pETR 432 without $v b b$ expression cassette & This work \\
\hline pJOE875 & E. coli/Streptomyces shuttle vector & Altenbuchner et al. (1992) \\
\hline
\end{tabular}

methanol) on antibiotic test disks (6.6 mm diameter; Difco) placed onto the solidified test plates. After $48 \mathrm{~h}$ incubation at $30^{\circ} \mathrm{C}$, the growth-inhibition zones of $M$. luteus were measured and the erythromycin titre $\left(\mathrm{g} \mathrm{l}^{-1}\right)$ was calculated using a standard curve.

\section{RESULTS}

\section{Expression of $v$ hb in S. lividans}

As no suitable expression vectors were available for $S a c$. erythraea in the public domain, the $u b b$ gene from Vitreoscilla sp. was first subcloned into $S$. lividans expression plasmids. After the expression of active $v b b$ in S. lividans TK24 was confirmed, Sac. erythraea could be transformed with these constructs.

The $v b b$ gene was amplified by PCR using pRED2 (Khosla \& Bailey, 1988a) as a template. The primers for this PCR reaction were designed to generate BamHI sites at both the $5^{\prime}$ and $3^{\prime}$ ends of the gene. An additional Ndel site at the $5^{\prime}$ end of the $v b b$ gene was also introduced. The PCR fragment was ligated into the BamHI-digested vector pIC19H (Marsh et al., 1984), resulting in the plasmid pETR352. After the nucleotide sequence of $v b b$ was confirmed by DNA sequencing, the gene was cloned as a $\mathrm{NdeI} / \mathrm{Bam} \mathrm{HI}$ or BamHI fragment into the Streptomyces expression vectors, pIJ6021 and pIJ4090, respectively (Bibb \& Janssen, 1986; Takano et al., 1995), resulting in the plasmids pETR364 and pETR355 (Fig. 1a). In pETR364, $v b b$ is under the control of the thiostrepton-inducible PtipA promoter, whereas in pETR355, vhb expression occurs from the constitutive PermE* promoter.

S. lividans TK24 cells containing either pETR364 or pETR355 were grown in $10 \mathrm{ml} \mathrm{SM}$ medium for $4 \mathrm{~d}$ to study $v h b$ expression. In the case of S. lividans TK24 harbouring pETR364, thiostrepton $\left(2-20 \mu \mathrm{g} \mathrm{ml}^{-1}\right)$ was added after $3 \mathrm{~d}$ to induce the PtipA promoter. VHb synthesis was observed in both expression systems, as shown by Western blot analysis (Fig. 1b). Whilst the expression of $v b b$ under the control of the PermE* promoter was constitutive, as expected, the PtipA promoter required induction with thiostrepton: $5 \mu \mathrm{g} \mathrm{ml}^{-1}$ thiostrepton was sufficient for full induction of the PtipA promoter under these conditions. Further increases in the thiostrepton concentration did not result in higher $\mathrm{VHb}$ production. Without addition of thiostrepton, almost no VHb-specific band was detected in Western blots. This indicates that the PtipA promoter is relatively tightly regulated in $S$. lividans TK24. Furthermore, the results from the Western blots indicate that the PtipA promoter is approximately five times more active in the induced state than is the PermE* promoter.

To verify that the synthesized VHb is biologically active, CO-difference spectrum assays were performed with crude extracts of S. lividans TK24 carrying pETR364 or pETR355. CO-difference spectra typical of active VHb were observed for both constructs: these showed a single specific peak at about $418-420 \mathrm{~nm}$ after $\mathrm{CO}$ 
(a)
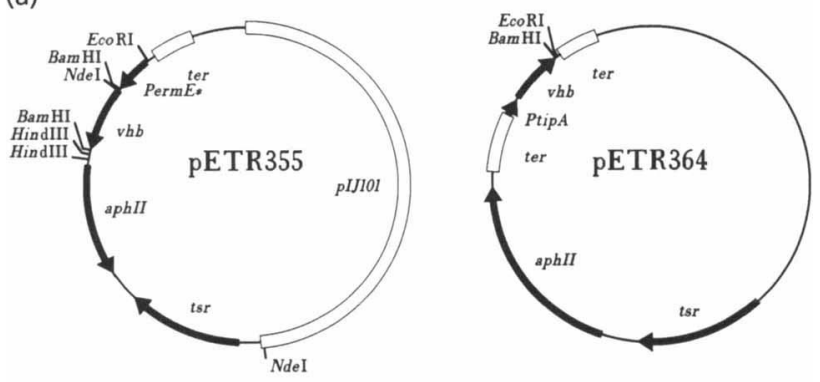

(b)

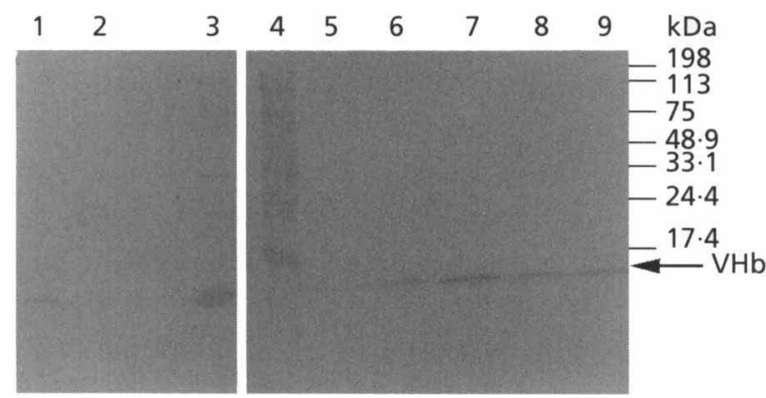

Fig. 1. (a) Restriction map of the $v h b$ expression plasmids pETR355 and pETR364. The vhb gene was amplified by PCR using pRED2 as the template with the primers $5^{\prime}$ GGATCCCATATGAACTTAAGGAAGACC-3' and 5'-GGATCCTTATTCAACCGCTTGAGC-3', and cloned as described. (b) Western blot analysis of crude extracts from S. lividans TK24 containing pETR355 (a plJ101 derivative; Hopwood et al., 1985) or pETR364. $10 \mu \mathrm{g}$ soluble protein was loaded in each lane. Lanes: 1, TK24/pETR355; 2, TK24; 3, positive control (crude extract from $E$. coli DH5 $\alpha /$ pRED2); 5, TK24/pETR364 uninduced; 6-9, TK 24/pETR364 induced with different thiostrepton concentrations (lane 6, $2 \mu \mathrm{g} \mathrm{ml}^{-1}$; lane $7,5 \mu \mathrm{g} \mathrm{ml}^{-1}$; lane $8,10 \mu \mathrm{g} \mathrm{ml}^{-1}$; lane 9, $20 \mu \mathrm{g} \mathrm{ml}^{-1}$ ) for $18 \mathrm{~h} ; 4$, protein marker broad range (Bio-Rad).

treatment of the soluble fraction, following reduction with sodium hydrosulphite (data not shown).

Although the $v b b$ expression vectors described above worked well in S. lividans TK24, we were unable to transform Sac. erythraea with these plasmids. Therefore, a set of alternative expression plasmids for $\mathrm{VHb}$ production was constructed based on different promoters and transformation procedures.

\section{Construction of a conjugable vhb expression plasmid}

Intergeneric conjugation of plasmids from E. coli to Sac. erythraea has been described by Mazodier et al. (1989) and seems in some cases to be even more efficient than transformation (Bierman et al., 1992). Thus, a vbb expression vector was constructed for conjugation into Sac. erythraea. An expression cassette consisting of the PermE* promoter, $v b b$ and the origin of transfer (oriT) from pPM927 (Smokvina et al., 1990) was cloned into the Streptomyces/E. coli shuttle vector pJOE875 (Altenbuchner et al., 1992), which contains the Streptomyces origin of replication from plasmid pIJ350 (Hopwood et al., 1983) and the pUC origin for replication in E. coli. The resulting plasmid was designated

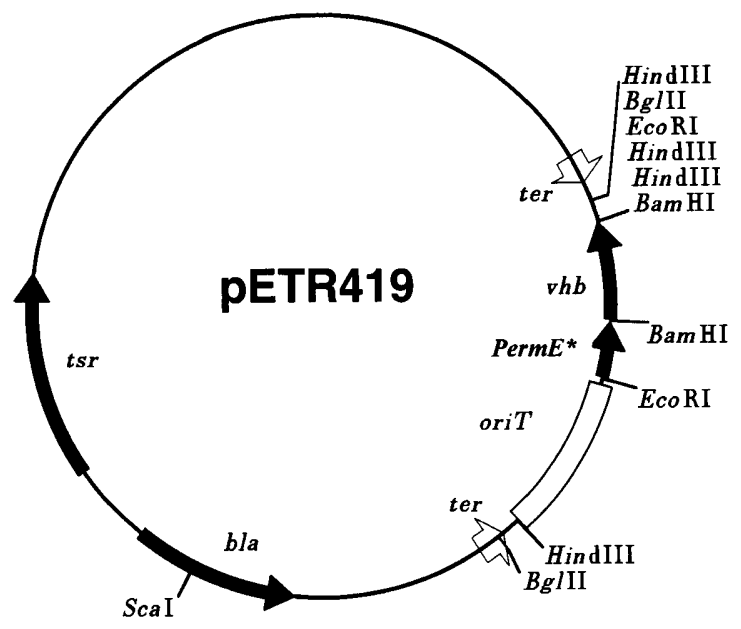

Fig. 2. Restriction map of the plasmid pETR419 containing the PermE*-vhb expression cassette and the origin of transfer (oriT) for intergeneric conjugation flanked by transcriptional terminators (ter). The plasmid is a shuttle vector which replicates in E. coli and Actinomycetes.

pETR419 (Fig. 2). After conjugation from E. coli S17.1 into Sac. erythraea, thiostrepton-resistant exconjugants were selected. Counterselection against $E$. coli was done with nalidixic acid $\left(40 \mu \mathrm{g} \mathrm{ml}^{-1}\right)$. The isolated Sac. erythraea exconjugants showed only very weak and not reproducible $\mathrm{VHb}$ activity, as judged by $\mathrm{CO}$-difference spectrum assays. As confirmed by plasmid isolations from exconjugants, the expression plasmids were not stably maintained and underwent recombination in Sac. erythraea (data not shown).

\section{Chromosomal integration of a vhb expression cassette in Sac. erythraea}

Plasmid instability prompted us to construct a vector for chromosomal integration of a $v b b$ expression cassette in Sac. erythraea. To avoid possible recombination in Sac. erythraea, the PermE* promoter was replaced by another constitutive Streptomyces promoter. It has previously been shown that the two promoters of the mercury-resistance determinant of S. lividans 1326 are constitutive in the absence of their negative regulator, MerR (Brünker et al., 1996). Since Sac. erythraea was not expected to contain this mercury-regulated repressor, the PmerR promoter was used for $v h b$ expression. PmerR and the $v b b$ gene were amplified by PCR, during which convenient restriction sites (SalI and EcoRI for PmerR; EcoRI and BamHI for $v b b$ ) were introduced to the end of the fragments and cloned into pIC19H, which only replicates in E. coli. In addition, the thiostrepton resistance gene $(t s r)$ was inserted into this plasmid for antibiotic selection in Sac. erythraea. The Streptomyces phage $\phi \mathrm{C} 31$ attachment site (att) (Chater, 1986) was included in the expression vector to facilitate homologous recombination with the Sac. erythraea chromosome. This was done on the assumption that Sac. erythraea also carries the $\phi \mathrm{C} 31$ att site. The resulting 


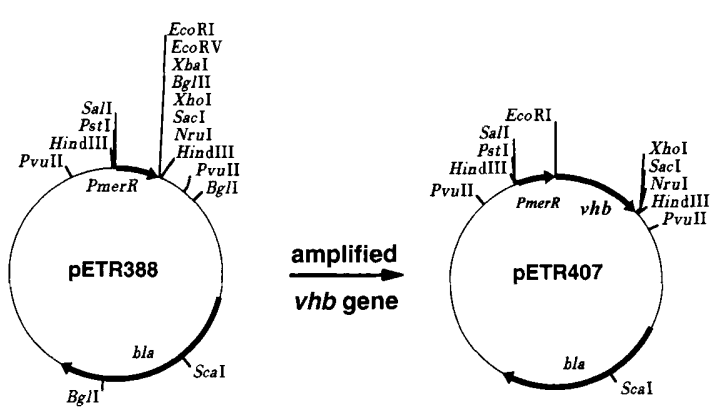

att $\phi$ C31 fragment
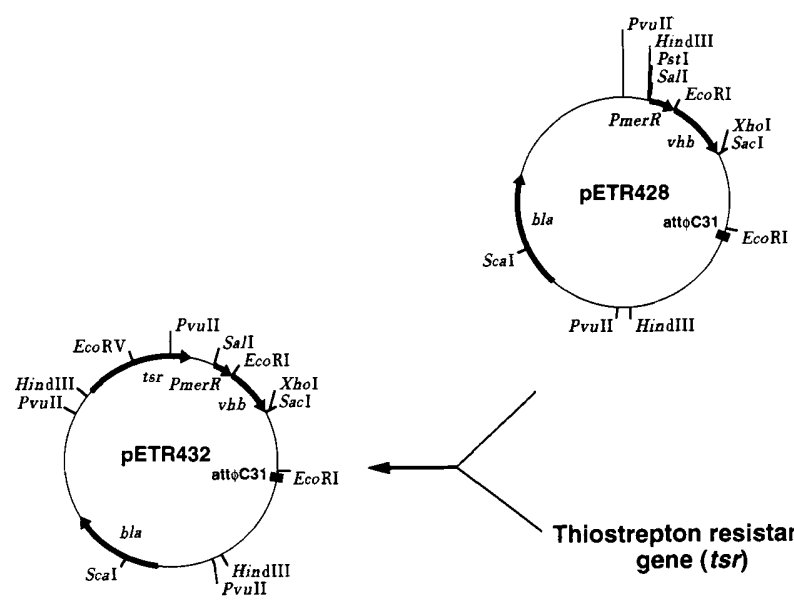

Thiostrepton resistance gene (tsr)

Fig. 3. Construction of pETR432. The PmerR promoter and vhb were amplified by PCR and cloned into the vector $\mathrm{plC} 19 \mathrm{H}$ to give the plasmid pETR407. Primers used in the PCR reactions were 5'-TTGTCGACCCGCGGCGAATGCGCCGG-3' and 5'-TTGAATTCCCTITCCACCAGCAGCTA-3' for PmerR, and 5'-TTGAATTCATGTIAGACCAGCAAACC-3' and 5'-GGATCCTTATTCAACCGCTTGAG$C-3^{\prime}$ for $v h b$, respectively. The $\phi C 31$ att site was isolated as a HindIII fragment (carrying the att site and the $5^{\prime}$ end of the integrase gene) from pJOE706 (not shown) and after filling in the ends with Klenow polymerase was inserted into the Nruldigested plasmid pETR407 to give pETR428. For selection the thiostrepton-resistance gene (tsr) from pJOE2139.1 (not shown) was cloned (Bg/ll/Xhol, Klenow) into pETR428 (Pstl, Klenow), resulting in pETR432.

plasmid, pETR432, contains $t s r$, PmerR- $v h b$ and att $\phi \mathrm{C} 31$, as shown in Fig. 3. This construct was transformed using a modified transformation procedure into S. lividans TK64 and Sac. erythraea as described above.

The chromosomal integration and expression of $v b b$ in transformants of both strains was demonstrated by Southern and Western blot analysis (Fig. 4a) and by PCR (data not shown). In addition, a DNA fragment was amplified from chromosomal DNA of Sac. erythraea that had been transformed with pETR432 using $v b b$-specific primers. The amplified fragment was cloned into pIC19H and sequenced to confirm that it had the correct DNA sequence of $v b b$.

Biological activity of synthesized $\mathrm{VHb}$ was demon- strated by CO-difference spectrum assays (Fig. 4b). A VHb-specific CO-difference spectrum was observed in crude extracts of S. lividans TK64::pETR432 and Sac. erythraea::pETR432 after treatment with CO, but no such peak could be detected with the untransformed control strains.

\section{Erythromycin accumulation in fed-batch shake-flask cultivations}

Erythromycin productivities of the recombinant $v b b$ expressing strain, Sac. erythraea::pETR432, the original Sac. erythraea strain and Sac. erythraea::pETR451 (lacking the $v b b$ expression cassette) were evaluated in shake-flask cultivations. The strains were grown in $30 \mathrm{ml}$ half-strength F1 medium in $250 \mathrm{ml}$ baffled shake flasks as described above. Samples $(200 \mu \mathrm{l})$ were taken every $24 \mathrm{~h}$ during cultivation and the erythromycin titres were determined by a bioassay. Results of these assays are shown in Fig. 5.

Sac. erythraea produced $3 \cdot 8-3.9 \mathrm{~g}$ erythromycin $1^{-1}$. A similar result $\left(3.6 \mathrm{~g}^{-1}\right)$ was obtained with the recombinant strain Sac. erythraea::pETR451. Under identical conditions, Sac. erythraea::pETR432 produced up to 6.3 g erythromycin $1^{-1}$, a value which was also obtained for other transformants (Fig. 5). This represents an increase in the product titre of approximately $60 \%$. With all strains, the maximum titre was reached at day 8 of the cultivation and then remained constant until the end of the fermentation, at day 9. In contrast to the original strain, erythromycin accumulation in Sac. erythraea::pETR432 seemed to be faster during the first $3 \mathrm{~d}$ of cultivation. After that the erythromycin accumulation rates remained the same in both strains until, at around days 7 and 8, a drastic increase in erythromycin accumulation was observed for the genetically engineered strain, compared to the original Sac. erythraea strain. As calculated from the total protein concentrations, the original Sac. erythraea and the recombinant strain $S a c$. erythraea::pETR432 produced similar biomasses during the cultivation $\left(1.6 \mathrm{~g} \mathrm{I}^{-1}\right.$ and $1.4 \mathrm{~g} \mathrm{l}^{-1}$ at day 9 , respectively).

\section{Stability of the recombinant strain of Sac. erythraea}

To determine the genetic stability of the chromosomally integrated $v b b$ expression cassette, the proportion of cells showing thiostrepton resistance was determined in cultures grown in the absence of thiostrepton. Cells from each sample taken for the erythromycin assays were plated onto R5 agar. Single colonies that emerged were replica-plated onto agar plates containing thiostrepton. The fraction of the colonies that remained thiostrepton resistant after $9 \mathrm{~d}$ cultivation in production medium without thiostrepton was greater than $97 \%$ (data not shown), demonstrating that the $v b b$ expression cassette was stably integrated into the chromosome of Sac. erythraea. 


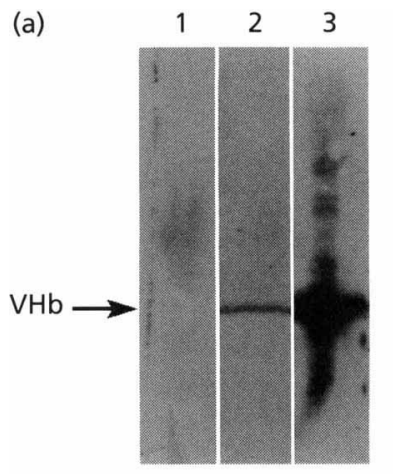

(b)

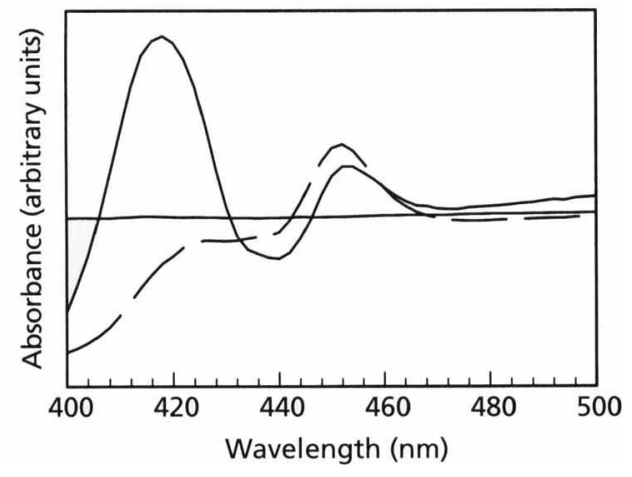

Fig. 4. Western blot analysis (a) and COdifference spectra (b) of cleared cell extracts $(10 \mu \mathrm{g}$ protein loaded) from Sac. erythraea (broken line) and Sac. erythraea::pETR432 (full line) after cultivation for $5 \mathrm{~d}$ in shake flasks. The difference in absorbance of $\mathrm{CO}$ treated and untreated samples is plotted. Lanes: 1, Sac. erythraea; lane 2, Sac. erythraea::pETR432; lane 3, E. coli/pRED2 (positive control).

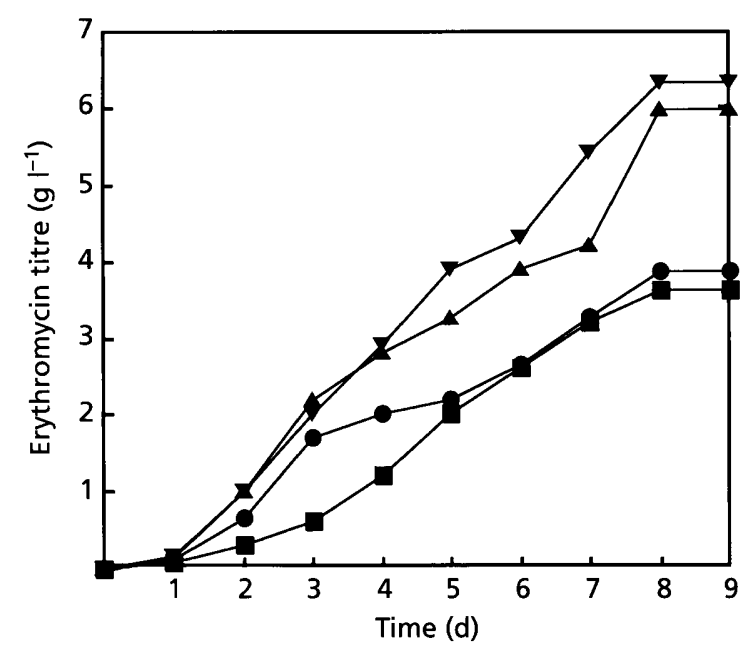

Fig. 5. Erythromycin accumulation with the strains Sac. erythraea (0) and Sac. erythraea::pETR432 no. 1 (A) during a $9 \mathrm{~d}$ shake-flask cultivation. The mean product titres from two independent cultivations for each strain are shown. In addition, the results obtained with a second transformant, Sac. erythraea::pETR432.6 $(\boldsymbol{\nabla})$, and the control strain, Sac. erythraea::pETR451 $(\boldsymbol{\square})$, are shown.

\section{DISCUSSION}

Several cloning strategies for the expression of the Vitreoscilla sp. $v$ bb gene in Streptomycetes have been tested. Initially, the $v h b$ gene was cloned and actively expressed in S. lividans TK24 using two different Streptomyces expression vectors (pIJ6021 and pIJ4090). Both plasmids have high copy numbers and can only replicate in Streptomyces spp. However, none of these expression plasmids could be transformed into Sac. erythraea by conventional transformation procedures. Even electroporation of mycelia or protoplasts did not yield any transformants. This inefficient transformation could be due in part to the small quantity and poor quality of the DNA isolated from $S$. lividans. However, transformation of poorly characterized, highly developed, and randomly mutagenized industrial production strains is often difficult, if not impossible, to achieve.
Reports on efficient intergeneric conjugation of plasmids from E. coli into several Streptomyces strains pointed to a reasonable alternative. It has been shown that, besides S. lividans and Streptomyces coelicolor, Streptomyces pristinaespiralis and Streptomyces viridochromogenes could be used as recipients in conjugation experiments (Mazodier et al., 1989). Furthermore, it was reported that plasmids could be conjugated into Streptomyces fradiae, Streptomyces ambofaciens and even into Saccharopolyspora spinosa, strains that are barely transformable by PEG-mediated protoplast transformation (Bierman et al., 1992). All of these conjugation systems require the origin of transfer (oriT) from RK2 in cis (Guiney \& Yakobson, 1983) and transfer functions supplied in trans from the donor strain E. coli S17.1. Therefore, a conjugable $v h b$ expression plasmid was constructed. The resulting plasmid, pETR419, was transformed into E. coli S 17.1 and then conjugated with Sac. erythraea to yield thiostrepton-resistant exconjugants. Although the selected clones seemed to synthesize small amounts of active $\mathrm{VHb}$, it turned out that the expression plasmids were unstable in Sac. erythraea. This instability could be in part a result of homologous recombination between the PermE* fragment of the expression plasmid and the chromosomal ermE region within the erythromycin biosynthesis cluster of this strain.

Thus, it was decided to integrate a $v b b$ expression cassette into the chromosome of Sac. erythraea and to replace PermE* with another constitutive promoter (PmerR) from S. lividans 1326. This construction was expected to reduce the likelihood of homologous recombination with the erythromycin biosynthetic genes. As the target for site-specific integration, the Streptomyces phage $\phi \mathrm{C} 31$ attachment site was chosen. This had previously been used for the successful integration of plasmids into the chromosomes of S. lividans, S. fradiae and S. ambofaciens (Bierman et al., 1992).

The resulting $v h b$-expressing construct, pETR432, which contained the PmerR-vhb expression cassette, the thiostrepton resistance gene $(t s r)$ and a fragment carrying the $\phi \mathrm{C} 31$ attachment site, was successfully transformed into Sac. erythraea. The chromosomal 
integration of $v h b$ was demonstrated by Southern blot analysis and PCR amplification of $v b b$ from chromosomal DNA extracted from Sac. erythraea: : pETR 432. All tested transformants showed the same restriction pattern in Southern blots. This indicates that integration of the plasmid had occurred at a specific site, which was probably the $\phi \mathrm{C} 31$ or similar phage attachment site of the Sac. erythraea chromosome. Integration at this site did not have negative effects on the erythromycin production or growth of the recombinant strain. Furthermore, the integration was shown to be stable for at least the duration of a single erythromycin production batch process $(9 \mathrm{~d})$ in the absence of selection pressure with thiostrepton.

$\mathrm{CO}$-difference spectrum assays confirmed the synthesis of active $\mathrm{VHb}$. A typical $\mathrm{VHb} \mathrm{CO}$-difference spectrum with an absorption maximum at $420 \mathrm{~nm}$ was observed in S. lividans. With crude extracts of Sac. erythraea::pETR432, two absorption maxima were detected: one at $450 \mathrm{~nm}$ and one at $418 \mathrm{~nm}$. Whilst the peak at $418 \mathrm{~nm}$ was clearly related to $v h b$ expression, the peak at $450 \mathrm{~nm}$ was probably generated by cytochrome P-450 monooxygenases in Sac. erythraea (Katz \& Donadio, 1995). The same $450 \mathrm{~nm}$ peak was also observed in CO-difference spectra of Sac. erythraea not expressing $v h b$. The absorption maximum at $418 \mathrm{~nm}$ demonstrated that active $\mathrm{VHb}$ was synthesized.

The most important outcome of this study was that erythromycin production in the genetically modified industrial production strain was not adversely affected. By contrast, shake-flask cultivations with Sac. erythraea::pETR 432 reproducibly showed a $60 \%$ higher erythromycin titre compared to the original, VHb-negative strain. The increase was mostly due to the higher erythromycin production rate during the first $3 \mathrm{~d}$ of cultivation and an additional strong increase after day 7. The increase in erythromycin accumulation in the recombinant strain is not due to a higher biomass production since the biomass yields of both strains were similar throughout the cultivation. Furthermore, no significant difference in mycelial fragmentation was observed between the two strains (decreased mycelial fragmentation may lead to increased productivity: Bushell et al., 1997). Therefore we assume that the improved erythromycin production in the $v b b$-expressing strain is a consequence of an increased erythromycin biosynthetic flux. This might be the result of an increased activity of an oxygen-dependent step in erythromycin synthesis, most likely the C-6 hydroxylation of 6deoxyerythronolide B by EryF (Katz \& Donadio, 1995) or/and the final hydroxylation step by EryK (Stassi et al., 1993).

We have described here for the first time successful genetic manipulation of an industrial erythromycinproducing strain of Sac. erythraea. The preliminary erythromycin production titres from shake flasks probably do not reflect the production potential of the new $v b b$-expressing strain since the culture conditions have not been optimized for this strain.

\section{ACKNOWLEDGEMENTS}

This work was supported by Solidago AG and Swiss KTI project no. 3034.1. We thank Dr M. Bibb, Department of Genetics, The John Innes Centre, for provision of the plasmids pIJ6021 and pIJ4090. The vectors pJOE706 and pJOE875 were kindly provided by Dr J. Altenbuchner, Institute for Industrial Genetics, University of Stuttgart. For critical reading of the manuscript we thank Dr D. Lasko, Institute of Biotechnology, ETH Zürich.

\section{REFERENCES}

Altenbuchner, J., Viell, P. \& Pelletier, I. (1992). Positive selection vectors based on palindromic DNA sequences. Methods Enzymol 216, 457-466.

Bailey, J. E. (1991). Toward a science of metabolic engineering. Science 252, 1668-1675.

Bibb, M. J. \& Janssen, G. R. (1986). Unusual features of transcriptions and translation of antibiotic resistance genes in antibiotic-producing Streptomyces. In Fifth International Symposium on the Genetics of Industrial Microorganisms, Zagreb, 1986, pp. 309-318. Edited by M. Alacevic, D. Hranueli \& Z. Toman. Karlovac: Ognjen Prica.

Bierman, M., Logan, R., O'Brian, K., Seno, E. T., Rao, N. R. \& Schoner, B. E. (1992). Plasmid cloning vectors for the conjugal transfer of DNA from Escherichia coli to Streptomyces spp. Gene 116, 43-49.

Birr, E., Wohlleben, W., Aufderheide, K. \& 7 other authors (1989). Isolation and complementation of mutants of Streptomyces coelicolor 'Müller' DSM30300 deficient in lysozyme production. Appl Microbiol Biotechnol 30, 358-363.

Bradford, M. M. (1976). A rapid and sensitive method for the quantitation of microgram quantities of protein utilizing the principle of protein-dye binding. Anal Biochem 72, 248-254.

Brüner, P., Rother, D., Sedlmeier, R., Klein, J., Mattes, R. \& Altenbuchner, J. (1996). Regulation of the operon responsible for broad-spectrum mercury resistance in Streptomyces lividans 1326. Mol Gen Genet 251, 307-315.

Bullock, W. O., Fernandez, J. M. \& Short, J. M. (1987). A high efficiency plasmid transforming recA Escherichia coli strain with $\beta$-galactosidase selection. Biotechniques 5, 376-377.

Bushell, M. E., Dunstan, G. L. \& Wilson, G. C. (1997). Effect of small scale culture vessel type on hyphal fragment size and erythromycin production in Saccharopolyspora erythraea. Biotechnol Lett 19, 849-852.

Chater, K. F. (1986). Streptomyces phages and their applications to Streptomyces genetics. In The Bacteria. A Treatise on Structure and Functions, pp. 119-158. Edited by S. W. Queener \& L. E. Day. Orlando, FL: Academic Press.

DeModena, J.A., Gutiérrez, S., Velasco, J., Fernández, F. J., Fachini, R. A., Galazzo, J. L., Hughes, D. E. \& Martin, J. F. (1993). The production of Cephalosporin $\mathrm{C}$ by Acremonium chrysogenum is improved by the intracellular expression of a bacterial hemoglobin. Bio/Technology 11, 926-929.

Gerhardt, B., Murray, R. G. E., Wood, W. A. \& Krieg, N. R. (editors) (1994). Manual of Methods for General Bacteriology. Washington, DC: American Society for Microbiology.

Guiney, D. G. \& Yakobson, E. (1983). Location and nucleotide sequence of the transfer origin of the broad host range plasmid RK2. Proc Natl Acad Sci USA 80, 3595-3598.

Holmberg, N., Lilius, G., Bailey, J. E. \& Bülow, L. (1997). Transgenic tobacco expressing Vitreoscilla hemoglobin exhibits 
enhanced growth and altered metabolic production. Nat Biotechnol 15, 244-247.

Hopwood, D. A., Kieser, T., Wright, H. M. \& Bibb, M. J. (1983). Plasmids, recombination and chromosome mapping in Streptomyces lividans 66. J Gen Microbiol 129, 2257-2269.

Hopwood, D. A., Bibb, M. J., Chater, K. F. \& 7 other authors (1985). Genetic Manipulation of Streptomyces. A Laboratory Manual. Norwich: The John Innes Foundation.

Kallio, P. T. \& Bailey, J. E. (1996). Intracellular expression of Vitreoscilla hemoglobin ( $\mathrm{VHb}$ ) enhances total protein secretion and improves the production of $\alpha$-amylase and neutral protease in Bacillus subtilis. Biotechnol Prog 12, 31-39.

Katz, L. \& Donadio, S. (1995). Macrolides. In Genetics and Biochemistry of Antibiotic Production, pp. 385-420. Edited by L. C. Vining \& C. Stuttard. Newton, MA: ButterworthHeinemann.

Khosla, C. \& Bailey, J. E. (1988a). The Vitreoscilla hemoglobin gene: molecular cloning, nucleotide sequence and genetic expression in E. coli. Mol Gen Genet 214, 158-161.

Khosla, C. \& Bailey, J. E. (1988b). Heterologous expression of a bacterial haemoglobin improves the growth properties of recombinant Escherichia coli. Nature 331, 633-635.

Lee, S.-Y. \& Rasheed, S. (1990). A simple procedure for maximum yield of high-quality plasmid DNA. Biotechniques 9, 976-979.

McKenney, K., Shimatake, H., Court, D., Schmeissner, U., Braty, C. \& Rosenberg, M. (1981). A system to study promoter and terminator signals recognized by Escherichia coli RNA polymerase. In Gene Amplification and Analysis, vol. 2, Analysis of Nucleic Acids by Enzymatic Methods, pp. 383-415. Edited by J. G. Chirikijan \& T. S. Papas. Amsterdam: Elsevier-North Holland.

MacNeil, D. J., Gewain, K. M., Ruby, C. L., Dezeny, G., Gibbons, P. H. \& MacNeil, T. (1992). Analysis of Streptomyces avermitilis genes required for avermectin biosynthesis utilizing a novel integration vector. Gene $111,61-68$.

Marsh, J. L., Erfle, M. \& Weykes, E. J. (1984). The pIC plasmid and phage vectors with versatile cloning sites for recombinant selection by insertional inactivation. Gene 32, 481-485.

Mazodier, P., Petter, R. \& Thompson, C. J. (1989). Intergeneric conjugation between Escherichia coli and Streptomyces species. J Bacteriol 171, 3583-3585.

Nakayama, I. (1984). Macrolides in clinical practice. In Macrolide Antibiotics: Chemistry, Biology and Practice, pp. 261-300. Edited by S. Omura. New York: Academic Press.
Pendse, G. J. \& Bailey, J. E. (1994). Effect of Vitreoscilla hemoglobin expression on growth and specific tissue plasminogen activator productivity in recombinant chinese hamster ovary cells. Biotechnol Bioeng 44, 1367-1370.

Sambrook, J., Fritsch, E. F. \& Maniatis, T. (1989). Molecular Cloning: a Laboratory Manual, 2nd edn. Cold Spring Harbor, NY: Cold Spring Harbor Laboratory.

Sander, F. C., Fachini, R. A., Hughes, D. A., Galazzo, J. L. \& Bailey, J. E. (1994). Expression of Vitreoscilla hemoglobin in Corynebacterium glutamicum increases final concentration and yield of L-lysine. In Proceedings of the 6th European Congress on Biotechnology, vol. 6, pp. 607-610. Edited by L. Alberghina, L. Frontali \& P. Sensi. Amsterdam: Elsevier.

Sanger, F., Nicklen, S. \& Coulson, A. R. (1977). DNA sequencing with chain-terminating inhibitors. Proc Natl Acad Sci USA 74, 5463-5467.

Simon, R., Priefer, U. \& Pühler, A. (1983). A broad host range mobilization system for in vivo genetic engineering: transposon mutagenesis in gram-negative bacteria. Bio/Technology 1 , 784-791.

Smokvina, T., Mazodier, P., Boccard, F., Thompson, C. J. \& Guérineau, M. (1990). Construction of a series of pSAM2-based integrative vectors for use in actinomycetes. Gene 94, 53-59.

Stassi, D., Donadio, S., Staver, M. J. \& Katz, L. (1993). Identification of a Saccharopolyspora erythraea gene required for the final hydroxylation step in erythromycin biosynthesis. J Bacteriol 175 , 182-189.

Takano, E., White, J., Thompson, C. J. \& Bibb, M. J. (1995). Construction of thiostrepton-inducible, high copy-number expression vectors for use in Streptomyces spp. Gene 166, 133-137.

Weber, J. M., Wierman, C. K. \& Hutchinson, C. R. (1985). A genetic analysis of erythromycin production in Streptomyces erythreus. J Bacteriol 164, 425-433.

Webster, D. A. \& Liu, C. Y. (1974). Reduced nicotinamide adenine dinucleotide cytochrome $o$ reductase associated with cytochrome o purified from Vitreoscilla. J Biol Chem 249, 4257-4260.

Winston, S. E., Fuller, S. A. \& Hurrell, J. G. R. (1987). Western blotting. In Current Protocols in Molecular Biology, pp. 10.8.1-10.8.6. Edited by F. M. Ausubel, R. Brent, R. E. Kingston, D. D. Moore, J. G. Seidman, J. A. Smith \& K. Struhl. New York: Wiley.

Received 11 March 1998; revised 28 May 1998; accepted 10 June 1998. 